\title{
Article
}

\section{Comparative Human Development Thresholds for Absolute and Relative Pro- poor Mobile Banking in Developing Countries}

\author{
Asongu, Simplice and Nwachukwu, Jacinta Chikaodi
}

Available at http://clok.uclan.ac.uk/25152/

Asongu, Simplice and Nwachukwu, Jacinta Chikaodi ORCID: 0000-0003-29879242 (2018) Comparative Human Development Thresholds for Absolute and Relative Pro-poor Mobile Banking in Developing Countries. Information Technology and People, 31 (1). pp. 63-83. ISSN 0959-3845

It is advisable to refer to the publisher's version if you intend to cite from the work. http://dx.doi.org/10.1108/ITP-12-2015-0295

For more information about UCLan's research in this area go to http://www.uclan.ac.uk/researchgroups/ and search for <name of research Group>.

For information about Research generally at UCLan please go to http://www.uclan.ac.uk/research/

All outputs in CLoK are protected by Intellectual Property Rights law, including Copyright law. Copyright, IPR and Moral Rights for the works on this site are retained by the individual authors and/or other copyright owners. Terms and conditions for use of this material are defined in the policies page. 
Comparative human development thresholds for absolute and relative pro-poor mobile banking in developing countries

Simplice Asongu and Jacinta Nwachukwu

January 2017 


\section{A G D I Working Paper}

\section{WP/17/007}

Comparative human development thresholds for absolute and relative propoor mobile banking in developing countries

Forthcoming: Information Technology \& People

\section{Simplice A. Asongu}

African Governance and Development Institute,

P.O. Box 8413 Yaoundé, Cameroon.

E-mail: asongusimplice@yahoo.com

\section{Jacinta C. Nwachukwu}

Department of Economics, Finance and Accounting,

Faculty of Business, Environment and Society, Coventry University

Priory Street, Coventry, CV1 5DH, UK

Email: jacinta.nwachukwu@ coventry.ac.uk 
Research Department

\title{
Comparative human development thresholds for absolute and relative pro-poor mobile banking in developing countries
}

\author{
Simplice A. Asongu \& Jacinta C. Nwachukwu
}

January 2017

\begin{abstract}
We assess the correlations between mobile banking and inclusive development (poverty and inequality) in 93 developing countries for the year 2011. Mobile banking entails: 'mobile phones used to pay bills' and 'mobile phones used to receive/send money', while the modifying policy indicator is the human development index (HDI). The data is decomposed into seven sub-panels based on two fundamental characteristics, namely: regions (Latin America, Asia and Pacific, Central and Eastern Europe, and Middle East and North Africa) and income levels (upper middle income, lower middle income and low income). Our results show that at certain thresholds of the HDI, mobile banking is positively linked to inclusive development. The following specific findings are established. First, the increased use of mobile phones to pay bills is negatively correlated with: (i) poverty in lower-middle-income countries (LMIC), upper-middle-income countries (UMIC) and Latin American countries (LA), respectively at HDI thresholds of $0.725,0.727$ and 0.778 and; (ii) inequality in UMIC and LA with HDI thresholds of respectively 0.646 and 0.761. Second, the increased use of mobile phones to send/receive money is negatively correlated with: (i) poverty in LMIC, UMIC and Central and Eastern European countries (CEE) with corresponding HDI thresholds of $0.631,0.750$ and 0.750 and (ii) inequality in UMIC, CEE and LA at HDI thresholds of $0.665,0.736$ and 0.726 respectively. The findings are discussed in the light of current policy challenges in the transition from Millennium Development Goals to Sustainable Development Goals. We have exploited the only macroeconomic data on mobile banking currently available.
\end{abstract}

JEL Classification: G20; O40; I10; I20; I32

Keywords: Mobile banking, quality of growth, poverty, inequality 


\section{Introduction}

Information technology has been shown to be beneficial in a plethora of ways, notably in changing society (Kreps \& Kimppa, 2015; Tatnall, 2015; Lennerfors et al., 2015; Patrignani \& Whitehouse, 2015; Lahtiranta et al., 2015; Aricat, 2015) and in improving human development (Venable et al., 2011; Kautz, 2011; Hossain \& Quaddus, 2011; Watts \& Wyner, 2011; Johri \& Nair, 2011; Gripenberg, 2011). The mobile money market is burgeoning, with estimates suggesting that by 2019, total annual transactions would be about US\$1.3 billion USD from the US\$655.8 million in 2014 (Caulderwood, 2015). This will represent substantial opportunities of financial inclusion which are needed for business development and for improvement in the living standards of a fraction of the population that hitherto has been excluded from formal financial activities. This position is further substantiated by evidence from the Global Findex Inclusion Database which indicates that the benefits of mobile banking are crucial because only 23 percent of adults in developing countries surviving on less than 2US\$/ a day possess a bank account.

The positive role of mobile banking/phones ${ }^{1}$ has been established to provide a multitude of inclusive development advantages, notably: women empowerment (Ojo et al., 2012; Maurer, 2008); bridging the rural-urban divide (Chan \& Jia, 2011, pp. 3-5; Qiang et al., 2011, pp. 14-26); promotion of financial inclusion (Singh, 2012, p. 466; Kirui et al. 2013, p. 141; Asongu, 2013a); improvement of health services for the poor (Kline et al., 2013); mitigation of income-inequality (Asongu, 2015ab); enhancement of business opportunities (Mishra \& Bisht, 2013, p. 505; Ondiege, 2010, p. 1); efficiency in the management of households (Al Surikhi, 2012; Asongu, 2016) and reduction of agricultural wastage via the elimination of excess in agriculture via stifling supply and demand-side constraints by means of restricting/limiting demand-supply mismatches (Aker \& Fafchamps, 2010; Muto \& Yamano, 2009).

With the above interesting background, some studies have cautioned that the mobile phone should not be considered a silver bullet for development (Asongu \& De Moor, 2015). Partly motivated by calls for more scholarly research on the development outcomes of mobile phones (Mpogole et al, 2008, p. 71), the World Bank has recently provided the scientific community with the first mobile banking macroeconomic database (Mosheni-Cheraghlou, 2013). This has provided an opportunity of analysing the role of mobile banking beyond the

\footnotetext{
${ }^{1}$ The term 'mobile phones' is used interchangeably with 'cell phones' and 'mobiles' throughout this paper.
} 
mainstream survey-based, country-specific and microeconomic studies (Kazi \& Mannan, 2013; Alsheikh \& Bojei, 2014; Cudjoe et al., 2015).

It is important to note that the mobile banking data from the World Bank is only available for the year 2011. Hence, because it is difficult to identify significant trends from a single data point per country, findings have to be interpreted as correlations, not causality. However, we argue that policy implications based on correlations could still provide substantial exploratory insights into potential trends when many countries are included. In this study, we are sampling 93 developing countries. Moreover, Asongu (2015a) has recently used the same indicators for a limited sample of African countries and interpreted the findings as correlations.

The relevance of assessing the relationship between mobile banking and inclusive development is further motivated by the current transition from Millennium Development Goals (MDGs) to Sustainable Development Goals (SDGs) that has shifted the policy debate from growth to inclusive growth. Interest in this policy debate has been reignited with the April 2015 publication by the World Bank of MDGs extreme poverty target achievements. The report shows that poverty has been decreasing in all regions of the world, with the exception of sub-Saharan Africa (Asongu \& Kodila-Tedika, 2015).

To the best of our knowledge, this study on the 'mobile-banking'-'inclusive development' relationship steers clear of previous literature on mobile banking and inclusive development in at least two ways. First, with regard to the former, the literature on mobile banking has been substantially based on using surveyed microeconomic data to assess mobile banking adoption intensions (Gu et al., 2009; Medhi et al., 2009; Daud et al., 2011; Akturan \& Tezcan, 2012; Kazi \& Mannan, 2013; Cudjoe et al., 2015; Alsheikh \& Bojei, 2014). We contribute to this stream by: (i) broadening the analytical scope to 93 developing countries from country-specific studies and (ii) focusing on macroeconomic data. Second, with respect to the latter, the inclusive development literature has fundamentally focused on: poverty correlates (Anyanwu, 2013a, 2014a); gender inequality (Anyanwu, 2013b, 2014b; Elu \& Loubert, 2013; Baliamoune-Lutz, 2007; Baliamoune-Lutz \& McGillivray, 2009); reinventing development assistance for inclusive and sustainable development (Asongu, 2016) and recent advances in finance for inclusive development (Asongu \& De Moor, 2015); measurements of inclusive development (Anand et al., 2013; Mlachila et al., 2014) and debates between relative pro-poor (Dollar \& Kraay, 2003) versus absolute pro-poor (Ravallion \& Chen, 2003) growth. The last-three streams are closest to the present line of inquiry because they entail: (i) 
mobile banking as a recent financial advancement for inclusive development (already discussed above), (ii) the newly published dataset by the International Monetary Fund (IMF) on quality of growth and (iii) absolute and relative pro-poor growth. According to Mlachila et al. (2015), absolute pro-poor growth is growth that yields reduction in poverty whereas relative pro-poor growth is growth that results in decreasing inequality. In what follows, the second point is substantiated concurrently with the discourse justifying the comparative dimension of the line of inquiry.

The comparative scope in this study is essentially motivated by the imperative of providing more space for policy implications. To this end, the data is decomposed into seven sub-panels based on two fundamental characteristics, namely: regions (Latin America, Asia and Pacific, Central and Eastern Europe, and the Middle East and North Africa) and income levels (upper middle income, lower middle income and low income). The justification for these comparative criteria aligns with two key stylized facts and insights from the inclusive development and mobile phones/banking literature.

First, with regard to the inclusive development issue, two points are noteworthy. They are: (i) Mlachila et al. (2014, p.13-14 which is the source of our inclusive development data) have employed the same disaggregation criteria to elicit fundamental variations in quality of growth and (ii) as we have highlighted earlier, the April $15^{\text {th }} 2015$ publication by the World Bank of World Development Indicators (WDI) has revealed that extreme poverty has been decreasing in all regions of the world with the exception of sub-Saharan Africa (SSA)( Asongu \& Kodila-Tedika, 2015; World Bank, 2015). Concerns about immiserizing growth in SSA can be justified because, on the one hand, seven out of the ten fastest growing economies in the world are in SSA (Asongu \& Rangan, 2016) and on the other hand, the sub-region has enjoyed more than two decades of growth resurgence (Fosu, 2015, p. 44).

It follows that the findings of the World Bank's that $45 \%$ of countries in SSA are offtrack from the MDG extreme poverty target can be taken into account if we provide SSAspecific findings for more targeted policy implications. Points (i) and (ii) above in the first justification are converged by Mlachila et al. (2014) in the perspective that, the authors have motivated the construction of the 'quality of growth index' (QGI) with documented evidence of immiserizng growth in SSA (Ola-David \& Oyelaran-Oyeyinka, 2014; Martinez \& Mlachila, 2013; Dollar et al., 2013; Dollar \& Kraay, 2002).

Second, we also discuss the comparative motivation of mobile phone/banking in two main streams, namely on mobile phones and mobile banking. They are: (i) consistent with 
Penard et al. (2012), compared to Asia, Europe and North America which already have saturated high-end mobile markets, there are still substantial mobile phone penetration growth opportunities in SSA and (ii) according to Mosheni-Cheraghlou (2013), compared to other regions of the world, African countries are in the drivers' seat in terms of mobile money applications (for sending/receiving money and/or payment of bills).

In light of the above, we disaggregate the dataset into seven sub-panels based on two fundamental features, namely income levels (upper middle income, lower middle income and low income) and regions (Latin America, Asia and Pacific, Middle East and North Africa and Central and Eastern Europe). In order to provide more space for policy implications, we employ a modifying human development variable. In essence, the human development index (HDI) is interacted with mobile banking indicators to assess at what thresholds of human development are the inclusive benefits of mobile banking achieved. Inclusive development is measured by indicators of inequality and poverty, whereas mobile banking entails: 'mobile phone usage for the payment of bills (\% of adults)' and 'mobile phone usage for sending/receiving of money (\% of adults). These are the only two indicators available at the time of the study from the World Bank. According to Mosheni-Cheraghlou (2013), it is within a popular framework that regulation and technological availability are the most relevant features positively affecting mobile banking, defined as: the usage of mobile phones to make payments and receive/send money.

The rest of the study is organized as follows. Section 2 provides theoretical underpinnings and reviews the relevant literature. The data and methodology are discussed in Section 3. The empirical analysis and discussion of results are covered in Section 4. Concluding implications and further directions are provided in Section 5.

\section{Theoretical highlights and literature review}

\subsection{Theoretical highlights}

The theoretical underpinning motivating the adoption of mobile phones for inclusive mobile banking benefits is consistent with theories on users' attitudes. The three dominant models according to Yousafzai et al. (2010, p. 1172) are, (i) the: theory of reasoned action (TRA), (ii) theory of planned behavior (TPB) and (iii) the technology acceptance model (TAM). These theories are in accordance with the position that the adoption of mobile phones entails complex and multifaceted processes, namely (i) an approach that is based on customers by managers and system developers on formation belief, contrary to a direct 
influence of attitudes and (ii) essential features such as combined considerations (utilitarian, personal, social and customers' behavioral and psychological features).

First, the Theory of Reasoned Action (TRA) pioneered by Bagozzi (1982), Ajzen and Fishbein (1980) and Fishbein and Ajzen (1975) assumes that, prior to adopting a specific attitude, customers are rational in their considerations of the plethora of implications that their actions may engender. It is a well grounded theory which focuses on determinants of consciously-intended attitudes. Moreover, it is also parsimonious, intuitive and insightful in the manner in which it elicits attitudes.

Second, the Theory of Planned Behavior (TPB) developed by Ajzen (1991) complements the TRA by identifying a fundamental set-back, which is the absence of a difference between individuals which have conscious control from those who do not. According to the narrative, perceived behavioural control (PBC) also affects actual behaviour and behavioural intentions, the first-two characteristics being normative and attitudinal factors. Hence, the extension of the TRA by the TPB takes into account scenarios whereby customers have limited situation control. In accordance with the underpinnings, three principal considerations are documented to influence human actions, notably: (i) behavioural beliefs on the plethora of possible results deriving from a particular attitude and assessments of underlying results, (ii) "normative beliefs about the normative expectations of others and the motivation to comply with these expectations" (Yousafzai et al., 2010, p. 1175-1176) and (iii) individuals' control beliefs on resources, opportunities in possessed and unpossessed resources as well as foreseen obstacles towards materialising and anticipating attitudes. From a comprehensive view: (i) behavioural beliefs lead to results in either favourable or unfavourable attitudes connected to the underlying behaviour (ii) 'normative beliefs' are linked to social pressure or perceived subjective norms and (iii) 'control beliefs' lead to perceived behavioural control.

Third, the Technology Acceptance Model (TAM) was pioneered by Davis (1989). Consistent with Yousafzai et al. (2007ab), the TAM has been developed to be a parsimonious and solid model. According to Davis, the TAM: (i) adjusts to the framework of the TRA and (ii) is based on the assumption that the adoption of a given technology by an individual can be explained by his/her voluntary intentions to accept and use the specified technology. Within this framework, intention is defined as the perception of the individual on the usefulness of the technology and attitude towards its usage. It is important to nuance the TAM with the perspective that macro-factors can also shape the adoption of technology beyond and above 
the attitude of individuals. Accordingly, the adoption of mobile payment mechanisms in some countries may also be involuntary.

The engaged theories above follow this line of inquiry that the adoption of mobile phones by customers is motivated by their perceived or potential rewards in inclusive development from the mobile banking applications. In what follows, we discuss some of the perceived gains in terms of inclusive development.

\subsection{Mobile phones/banking and inclusive development}

Consistent with Asongu and De Moor (2015), in developing countries almost every fabric of society has been affected by the mobile revolution. Some of the documented advantages include: better corporate and household management, improvement of businessto-business networks, ameliorated systems for the monitoring of health care, better payment channels for Small and Medium Size Enterprises (SMEs), household-to-household and household-to-business interactions, education in terms of skills and training, reduction of rural-urban gaps and women empowerment. To the best of our knowledge, the inclusive development literature related to mobile phone/banking can be engaged in three main strands, notably: bridging of the gender-gap, improvement of health services and reduction of the rural/urban gap.

In the first strand regarding the mitigation of the gender gap, evidence on the crucial role of mobiles in the empowerment of females has been documented in a substantial body of literature. Some mobile phone/banking mechanisms through which the female gender can be empowered include (i) education, cost-reduction and multi-tasking (Asongu, 2015ab; Ondiege, 2013; Al Surikhi, 2012; Ondiege, 2010; Jonathan \& Camilo, 2008) and (ii) improved coordination of household activities and SMEs that are managed by women (Asongu, 2015a). Studies in this strand are consistent with the need for relevant government policies in facilitating inclusive mobile phone/banking benefits, notably (i) Maurer (2008) on the central role of policy in promoting and sustaining mechanisms by which mobiles improve gender inclusiveness and (ii) Ojo et al. (2012) on the utilization of mobile phones by Ghanaian women to improve their livelihoods. Country-specific approaches/strategies have been documented by Bisht (2013, p. 505) and Ondiege (2010, p. 11).

The second aspect which fundamentally focuses on reducing the rural-urban gap can be engaged in three main currents, notably: support of SMEs and cooperatives on the one hand and production and distribution of food in rural communities on the other, as well as 
mitigation of demand- and supply-side constraints in agricultural productivity and concerns about unemployment. Mobile banking is increasingly improving agricultural finance through (i) support for cooperatives and SMEs. Some examples include Community Credit Enterprises (CCE) that are ameliorating the sustainability of business models (Asongu \& De Moor, 2015) and financially-sustainable groups in Costa Rica (Perez et al., 2011, p. 316). (ii) Consistent with the engaged literature, mobile technology is increasingly being devoted to mitigating demand- and supply-side constraints in rural communities (Muto \& Yamano, 2009; Aker \& Fafchamps, 2010). This reduction has consolidated and improved farmers' income as well as opportunities of growth. In summary, the fundamental concerns addressed by this are channels via which mobile phones mitigate demand- and supply-wastages with the help of matching practices and networks. Finally, employment challenges on the one hand and the production and distribution of food on the other are increasingly been tackled with the help of mobile phone applications. Some case studies have shown that enhanced market information by means of such mobile technology improves traders' income by about 10 percent (Eagriculture, 2012, p. 6-9).

In summary, according to Warren (2007), the appeal of mobile phones are visible in improving the living standards of rural communities because, relative to urban areas, these communities are confronted with more barriers to information acquisition and the purchase of commodities which are lifted with the help of mobile applications. For example, in India, Singh (2012, p. 466) has shown that mobile banking is consolidating financial inclusion in rural communities because, in spite of efforts devoted towards increasing the appeal of formal financial institutions, 'Telecommunication infrastructure growth especially mobile phone penetration has created an opportunity for providing financial inclusion' (Mishra \& Bisht, 2013, p. 503).

The third strand is concerned about health services. Mobile phone/banking applications are continuously improving medical services and healthcare delivery. These mobile applications have rendered mobile health services of better quality to be more affordable (West, 2013). Hence, income and geographical constraints are being eased with the evolving usage of mobile phone applications in order to enhance health service delivery. Mechanisms by which health services are being improved entail access to medical record, laboratory test and reference material. It is in this respect that mobile applications are growingly being adapted for, inter alia: clinical appointments (Da Costa et al., 2010); enhanced observation and treatment of patients with tuberculosis (Hoffman et al., 2010) and 
better tailored feedbacks by means of enhanced self-monitoring (Bauer et al., 2010). The position that rural communities have been the greatest beneficiaries of health-related mobile applications by Kliner et al. (2013) has been confirmed by Kirui et al. (2013) within the spectrum of absolute pro-poor externalities from mobile phone/banking: 'We conclude that mobile phone-based money transfer services in rural areas help to resolve a market failure that farmers face; access to financial services' (p. 141). It is important to note that, the discussion of the role of mobile devices for health information, whilst relevant to development, is somewhat tangential to the discussion relating to financial inclusion. In essence, a person may have a mobile phone for health reasons and then use it for financial purposes.

The three strands above are consistent with World Bank's position on the critical role of mobile phone/banking in agricultural and rural development (Qiang et al., 2011, pp. 1426). This perspective is consistent with Chan and Jia (2011) on the inclusive rewards of mobile telephony in enhancing access to finance 'mobile banking is an ideal choice for meeting the rural financial needs' (p. 3) due to increasing 'rates for bank transfers through mobile cell phones at commercial banks' (p. 5).

\section{Data and Methodology}

\subsection{Data}

In line with the discussion above, we have two data sources. The first, from Mlachila et al. (2014) on inclusive development consists of four non-overlapping intervals (1990-1994; 1995-1999; 2000-2004 and 2005-2011) from 93 countries, whereas the second from MosheniCheraghlou (2013) on mobile banking is for the year 2011. The matching exercise results in us adopting a cross sectional data structure for the year 2011 because, as far as we know, macroeconomic mobile banking data is only available for this year. The two main mobile banking indicators are: 'mobile phone usage for the payment of bills (\% of adults)' and 'mobile phone usage for sending/receiving of money (\% of adults). In accordance with the pro-poor definitions provided in the introduction, the mobile banking effects on absolute propoor and relative pro-poor are measured with the poverty rate and inequality indices respectively.

In accordance with the engaged inclusive development literature (Asongu \& Rangan, 2016; Anand et al., 2013; Asongu \& Nwachukwu, 2016ab), adopted control variables include: education spending, government stability, credit, inflation, foreign direct investment (FDI) 
and remittances, whereas the modifying or threshold human development variable is the human development index (HDI). The definitions of the variables are provided in Appendix 1.

With regard to the expected signs, we anticipate the remaining variables to decrease poverty and inequality. However, the expected sign for inflation is difficult to establish because while low and stable inflation are conducive for pro-poor development, chaotic or high inflation increases inequality (Asongu, 2013b). This is essentially because, very high inflation discourages the investment needed for economic growth. In essence, investors have been documented to prefer investment strategies that are less ambiguous (Le Roux \& Kelsey, 2016; Kelsey \& Le Roux, 2016).

On the other hand, the corresponding positive covariates have been substantially documented in the inclusive development literature (Barro \& Lee, 2000; Dollar \& Kraay, 2003; Calderon \& Servén, 2004; Levine, 2005; IMF, 2007; Hausmann et al., 2007; Mishra, et al., 2011; Anand et al., 2012; Seneviratne \& Sun, 2013; Asongu \& Nwachukwu, 2016c). We devote space to briefly substantiating these expected positive signs. In accordance with the IMF (2007) and Anand et al. (2013), macroeconomic stability, structural change and human capital are fundamental drivers of inclusive development in developing countries. Structural change also entails, globalisation (e.g foreign direct investment- FDI), human capital and macroeconomic stability. Other documented macroeconomic and structural characteristics critical for inclusive development include: financial access (Levine, 2005), less volatile negative output and stable/low inflation (Barro \& Lee, 2010; Dollar \& Kraay, 2003), modernization of facilities of production (Mishra et al., 2011), infrastructural improvement (Calderon \& Servén, 2004; Seneviratne \& Sun, 2013) and enhancement of value chains (Hausmann et al., 2007; Anand, et al., 2012).

We have already justified the choice of seven fundamental characteristics from Mlachila et al. (2014) in the Introduction. Accordingly, these are based on two criteria (income levels and regions). Differences in fundamental characteristics are important because, since a challenge to the data is that only two data points per country are available, context becomes particularly important. For example, the use of mobile banking may be relatively low in the United Kingdom (UK) compared to Somalia because of the widespread availability of Automatic Teller Machines (ATMs) in the UK. This study accounts for this difference in context by distinguishing between high income and low income countries.

The summary statistics are presented in Appendix 2 while the correlation matrix is disclosed in Appendix 3. From the former, we notice that: (i) the means are comparable and 
(ii) the variables display a substantial degree of variation, such that we should be confident that significant estimated linkages should emerge. The objective of the latter is to control for potential issues of multicollinearity. We notice a high degree of substitution between the two mobile banking variables (highlighted in bold) at the height of 0.865 . This concern of multicollinearity is addressed by tailoring the specifications to avoid entering all the mobile banking variables into the same equation.

\subsection{Methodology}

Given that the data structure is cross-sectional, we adopt an estimation strategy that is consistent with such a structure. Previous inclusive development (Andrés, 2006), mobile phone (Asongu, 2013a, 2015a) and human development (Kodila-Tedika \& Asongu, 2015) studies based on the same data structure have employed heteroscedasitcity-consistent Ordinary Least Squares (OLS). Hence, Equation 1 below examines the correlation between inclusive development and mobile banking.

$$
I D_{i}=\alpha_{1}+\alpha_{2} M B_{i}+\alpha_{3} M B H D_{i}+\alpha_{4} X_{i}+\varepsilon_{i}
$$

Where: $I D_{i}\left(M B_{i}\right)$ represents an (a) inclusive development (mobile banking) indicator for country $i \alpha_{1}$ is a constant, $X$ is the vector of control variables and $\varepsilon_{i}$ the error term. ID includes: the poverty rate and inequality index. MB comprises the two mobile banking variables discussed in the preceding section, whereas HD is the human development index. MBHD is the interaction between mobile banking and human development, and $\mathrm{X}$ embodies educational spending, government stability, credit, inflation, FDI and remittances.

Given that interactions are involved in the specifications, we devote space to clarifying some pitfalls of interactive regressions documented by Brambor et al. (2006). In order for the estimations to make economic sense, the corresponding interactive coefficients are interpreted as conditional marginal correlations. Moreover, the modifying HDI should be within the range provided by the summary statistics for the underlying marginal correlations to have economic meaning.

\section{Empirical results}

Table 1 and Table 2 respectively present results corresponding to poverty and inequality. Whereas Panel A of all tables provides findings on 'mobile phones used to pay bills', the results of Panel B are related to 'mobile phones used to send/receive money'. Before 
engaging table-specific results, it is important to clarify two concerns in order to improve readability, namely, the: nature of signals and expected signs of thresholds for inclusive development. First, poverty and inequality are negative inclusive development signals. Second, for mobile banking to stimulate inclusive development, negative thresholds from the modifying variable are required to influence poverty and inequality for the absolute pro-poor and the relative pro-poor respectively.

The following findings can be established from Table 1 on linkages between 'mobile banking, poverty and human development'. First in Panel A, the increased use of mobiles to pay bills decreases poverty in lower-middle-income countries (LMIC), upper-middle-income countries (UMIC) and Latin American countries (LA). The modifying negative thresholds are within the HDI range ( 0.280 to 0.809$)$ provided by the summary statistics, notably: 0.725 (0.066/0.091) for LMIC, (ii) 0.727 (0.008/0.011) for UMIC and (iii) $0.778(0.253 / 0.325)$ for LA. Second in Panel B, increased use of mobiles to send/receive money decreases poverty in lower-middle-income countries (LMIC), upper-middle-income countries (UMIC) and Central \& Eastern European countries (CEE). The modifying negative thresholds are within the HDI range $(0.280$ to 0.809$)$ provided by the summary statistics, notably: $0.631(0.012 / 0.019)$ for LMIC, (ii) $0.750(0.003 / 0.004)$ for UMIC and (iii) $0.750(0.009 / 0.012)$ for CEE.

Table 1: Mobile banking, human development and Poverty

\begin{tabular}{|c|c|c|c|c|c|c|c|c|}
\hline & \multicolumn{8}{|c|}{ Panel A: Mobile use for Payment of Bills (Mobile.Pay) } \\
\hline & \multicolumn{3}{|c|}{ Income Levels } & \multicolumn{4}{|c|}{$\begin{array}{ll}\text { Regions } & \end{array}$} & \multirow[b]{2}{*}{ SSA } \\
\hline & LIC & LMIC & UMIC & $\mathrm{AP}$ & CEE & LA & MENA & \\
\hline Constant & $\begin{array}{l}0.074 \\
(0.467)\end{array}$ & $\begin{array}{l}-0.044 \\
(0.427)\end{array}$ & $\begin{array}{l}0.025^{* *} \\
(0.038)\end{array}$ & $\begin{array}{l}0.071 \\
(0.665)\end{array}$ & $\begin{array}{l}-0.014 * * \\
(0.033)\end{array}$ & $\begin{array}{l}-0.129 \\
(0.399)\end{array}$ & na & $\begin{array}{l}0.038 \\
(0.727)\end{array}$ \\
\hline Mobile.Pay & $\begin{array}{l}0.096^{*} \\
(0.086)\end{array}$ & $\begin{array}{l}0.066 \text { ** } \\
(0.013)\end{array}$ & $\begin{array}{l}0.008^{* * *} \\
(0.012)\end{array}$ & $\begin{array}{l}-0.042 \\
(0.591)\end{array}$ & $\begin{array}{l}-0.0005 \\
(0.102)\end{array}$ & $\begin{array}{l}0.253^{*} \\
(0.093)\end{array}$ & & $\begin{array}{l}0.027 \\
(0.754)\end{array}$ \\
\hline Mobile.Pay* HDI & $\begin{array}{l}-0.173 \\
(0.102)\end{array}$ & $\begin{array}{l}-0.091 \text { ** } \\
(0.011)\end{array}$ & $\begin{array}{l}-0.011 * * * \\
(0.009)\end{array}$ & $\begin{array}{l}0.025 \\
(0.821)\end{array}$ & $\begin{array}{l}0.0007 \\
(0.101)\end{array}$ & $\begin{array}{l}-0.325^{*} \\
(0.092)\end{array}$ & & $\begin{array}{l}-0.059 \\
(0.737)\end{array}$ \\
\hline Educational Spending & $\begin{array}{l}-0.131 \\
(0.663)\end{array}$ & $\begin{array}{l}0.063 \\
(0.313)\end{array}$ & $\begin{array}{l}-0.021 \\
(0.132)\end{array}$ & $\begin{array}{l}-0.125 \\
(0.564)\end{array}$ & $\begin{array}{l}0.015 * * \\
(0.027)\end{array}$ & $\begin{array}{l}0.097 \\
(0.538)\end{array}$ & & $\begin{array}{l}-0.128 \\
(0.658)\end{array}$ \\
\hline Government Stability & $\begin{array}{l}-0.008 \\
(0.420)\end{array}$ & $\begin{array}{l}-0.005 \\
(0.301)\end{array}$ & $\begin{array}{l}-0.00005 \\
(0.881)\end{array}$ & $\begin{array}{l}-0.005 \\
(0.450)\end{array}$ & $\begin{array}{l}0.00005 \\
(0.705)\end{array}$ & $\begin{array}{l}0.007 \\
(0.225)\end{array}$ & & $\begin{array}{l}-0.004 \\
(0.814)\end{array}$ \\
\hline Inflation & $\begin{array}{l}0.006 \\
(0.647)\end{array}$ & $\begin{array}{l}-0.001 \\
(0.364)\end{array}$ & $\begin{array}{l}-\mathbf{0 . 0 0 0 3 *} \\
(0.088)\end{array}$ & $\begin{array}{l}0.004 \\
(0.584)\end{array}$ & $\begin{array}{l}0.00008 \\
(0.240)\end{array}$ & $\begin{array}{l}0.001 \\
(0.327)\end{array}$ & & $\begin{array}{l}0.016 \\
(0.162)\end{array}$ \\
\hline Credit & $\begin{array}{l}-0.0004 \\
(0.714)\end{array}$ & $\begin{array}{l}-0.0001 \\
(0.565)\end{array}$ & $\begin{array}{l}-0.00001 \\
(0.509)\end{array}$ & $\begin{array}{l}0.0004 \\
(0.413)\end{array}$ & $\begin{array}{l}0.00002 \\
(0.221)\end{array}$ & $\begin{array}{l}0.00001 \\
(0.918)\end{array}$ & & $\begin{array}{l}0.0001 \\
(0.700)\end{array}$ \\
\hline Foreign Direct Investment & $\begin{array}{l}0.017 \\
(0.124)\end{array}$ & $\begin{array}{l}0.001 \\
(0.410)\end{array}$ & $\begin{array}{l}-0.0001 \\
(0.598)\end{array}$ & $\begin{array}{l}0.004 \\
(0.312)\end{array}$ & $\begin{array}{l}-0.0001 \\
(0.312)\end{array}$ & $\begin{array}{l}-0.0006 \\
(0.899)\end{array}$ & & $\begin{array}{l}0.006 \\
(0.252)\end{array}$ \\
\hline Remittances & $\begin{array}{l}0.001 \\
(0.974)\end{array}$ & $\begin{array}{l}0.002 * \\
(0.053)\end{array}$ & $\begin{array}{l}-0.0005 \\
(0.375)\end{array}$ & $\begin{array}{l}0.005 \\
(0.308)\end{array}$ & $\begin{array}{l}\text { 0.0001*** } \\
(0.039)\end{array}$ & $\begin{array}{l}0.002 * \\
(0.078)\end{array}$ & & $\begin{array}{l}0.004 * * \\
(0.026)\end{array}$ \\
\hline $\mathrm{R}^{2}$ & 0.252 & 0.629 & 0.721 & 0.909 & 0.740 & 0.818 & & 0.311 \\
\hline Fisher & $2.67 * *$ & 2.22* & 3.60 ** & 2.08 & $28.85 * * *$ & 4.96* & & $5.55 * * *$ \\
\hline
\end{tabular}




\begin{tabular}{|c|c|c|c|c|c|c|c|c|}
\hline & \multicolumn{8}{|c|}{ Panel B: Mobile for sending and receiving money (Mobile.SR) } \\
\hline & \multicolumn{3}{|c|}{ Income Levels } & \multicolumn{5}{|c|}{ Regions } \\
\hline & LIC & LMIC & UMIC & AP & CEE & LA & MENA & SSA \\
\hline Constant & $\begin{array}{l}0.109 \\
(0.222)\end{array}$ & $\begin{array}{l}-0.006 \\
(0.874)\end{array}$ & $\begin{array}{l}-0.023 \\
(0.152)\end{array}$ & $\begin{array}{l}0.034 \\
(0.820)\end{array}$ & $\begin{array}{l}0.003 \\
(0.705)\end{array}$ & $\begin{array}{l}-0.254 \\
(0.208)\end{array}$ & na & $\begin{array}{l}0.046 \\
(0.650)\end{array}$ \\
\hline Mobile.SR & $\begin{array}{l}0.021 \\
(0.603)\end{array}$ & $\begin{array}{l}0.012 * * * \\
(0.000)\end{array}$ & $\begin{array}{l}0.003 * * \\
(0.049)\end{array}$ & $\begin{array}{l}-0.016 \\
(0.912)\end{array}$ & $\begin{array}{l}0.009 * * \\
(0.037)\end{array}$ & $\begin{array}{l}0.058 \\
(0.615)\end{array}$ & & $\begin{array}{l}-0.003 \\
(0.658)\end{array}$ \\
\hline Mobile.SR* HDI & $\begin{array}{l}-0.038 \\
(0.639)\end{array}$ & $\begin{array}{l}-0.019 * * * \\
(0.000)\end{array}$ & $\begin{array}{l}-0.004 * \\
(0.085)\end{array}$ & $\begin{array}{l}0.002 \\
(0.991)\end{array}$ & $\begin{array}{l}-0.012 * * \\
(0.038)\end{array}$ & $\begin{array}{l}-0.067 \\
(0.700)\end{array}$ & & $\begin{array}{l}0.006 \\
(0.676)\end{array}$ \\
\hline Educational Spending & $\begin{array}{l}-0.063 \\
(0.843)\end{array}$ & $\begin{array}{l}0.026 \\
(0.446)\end{array}$ & $\begin{array}{l}0.026 \\
(0.155)\end{array}$ & $\begin{array}{l}0.033 \\
(0.877)\end{array}$ & $\begin{array}{l}-0.003 \\
(0.745)\end{array}$ & $\begin{array}{l}0.214 \\
(0.232)\end{array}$ & & $\begin{array}{l}-0.205 \\
(0.372)\end{array}$ \\
\hline Government Stability & $\begin{array}{l}-0.006 \\
(0.591)\end{array}$ & $\begin{array}{l}-0.002 \\
(0.603)\end{array}$ & $\begin{array}{l}-0.0001 \\
(0.437)\end{array}$ & $\begin{array}{l}-0.005 \\
(0.474)\end{array}$ & $\begin{array}{l}-0.00001 \\
(0.882)\end{array}$ & $\begin{array}{l}0.003 \\
(0.496)\end{array}$ & & $\begin{array}{l}-0.0003 \\
(0.982)\end{array}$ \\
\hline Inflation & $\begin{array}{l}0.004 \\
(0.783)\end{array}$ & $\begin{array}{l}-0.002 \\
(0.173)\end{array}$ & $\begin{array}{l}0.00006 \\
(0.415)\end{array}$ & $\begin{array}{l}-0.006 \\
(0.368)\end{array}$ & $\begin{array}{l}-0.00003 \\
(0.585)\end{array}$ & $\begin{array}{l}0.002 \\
(0.219)\end{array}$ & & $\begin{array}{l}0.018 * \\
(0.092)\end{array}$ \\
\hline Credit & $\begin{array}{l}-0.0005 \\
(0.768)\end{array}$ & $\begin{array}{l}-0.0002 \\
(0.322)\end{array}$ & $\begin{array}{l}0.00001 \\
(0.126)\end{array}$ & $\begin{array}{l}-0.0002 \\
(0.658)\end{array}$ & $\begin{array}{l}0.000 \\
(0.929)\end{array}$ & $\begin{array}{l}0.0002 \\
(0.495)\end{array}$ & & $\begin{array}{l}0.0001 \\
(0.747)\end{array}$ \\
\hline Foreign Direct Investment & $\begin{array}{l}0.013 \\
(0.189)\end{array}$ & $\begin{array}{l}0.001 \\
(0.396)\end{array}$ & $\begin{array}{l}-0.00007 \\
(0.660)\end{array}$ & $\begin{array}{l}0.006 \\
(0.142)\end{array}$ & $\begin{array}{l}0.000 \\
(0.885)\end{array}$ & $\begin{array}{l}0.004 \\
(0.329)\end{array}$ & & $\begin{array}{l}0.007 \\
(0.172)\end{array}$ \\
\hline Remittances & $\begin{array}{l}-0.002 \\
(0.477)\end{array}$ & $\begin{array}{l}0.003 * \\
(0.077)\end{array}$ & $\begin{array}{l}0.0001 \\
(0.667)\end{array}$ & $\begin{array}{l}0.009 \\
(0.163)\end{array}$ & $\begin{array}{l}-0.000 \\
(0.245)\end{array}$ & $\begin{array}{l}0.003 * \\
(0.070)\end{array}$ & & $\begin{array}{l}0.005 * * * \\
(0.005)\end{array}$ \\
\hline $\mathrm{R}^{2}$ & 0.227 & 0.611 & 0.875 & 0.927 & 0.788 & 0.795 & & 0.311 \\
\hline Fisher & 1.87 & $9.48 * * *$ & $125.92 * * *$ & 5.95 & $4.61 * *$ & $5.33 *$ & & $4.48 * * *$ \\
\hline Observations & 25 & 30 & 18 & 11 & 15 & 13 & & 26 \\
\hline
\end{tabular}

***; **;*: significance levels of 1\%, 5\% and 10\% respectively. LIC: Low Income Countries. LMIC: Lower Middle Income Countries. UMIC: Upper Middle Income Countries. AP: Asia and Pacific. CEE: Central and Eastern Europe. LA: Latin America. MENA: Middle East and North Africa. Mobile.Pay: Mobile for the payment of bills. Mobile. SR: Mobile for the Sending and Receiving in Money. HDI: Human Development Index. No regressions are performed for the MENA region because of issues with degrees of freedom.

The following findings can be established from Table 2 on linkages between 'mobile banking, inequality and human development'. First in Panel A, the increased use of the mobiles to pay bills decreases inequality in upper-middle-income countries (UMIC) and Latin American countries (LA). The modifying negative thresholds are within the HDI range $(0.280$ to 0.809$)$ provided by the summary statistics, notably: (i) $0.646(18.549 / 28.697)$ for UMIC and (ii) $0.761(43.778 / 57.509)$ for LA. Second in Panel B, increased use of mobiles to send/receive money decreases inequality in upper-middle-income countries (UMIC), Central \& Eastern European countries (CEE) and Latin American countries (LA). The modifying negative thresholds are within the HDI range (0.280 to 0.809$)$ provided by the summary statistics, notably: 0.665 (36.447/54.756) for UMIC, (ii) $0.736(31.426 / 42.67)$ for CEE and (iii) $0.726(22.437 / 30.876)$ for LA.

In Tables 1-2, most of the significant control variables display the expected signs: government stability and remittances decrease inequality. However, it should be noted that, we do not expect the control variables to display consistent signs across fundamental 
characteristics (or sub-panels) because inclusive development dynamics cross income levels and world regions reflect different tendencies. This position is consistent with the basis for disaggregating the dataset into fundamental features.

Table 2: Mobile banking, human development and inequality

\begin{tabular}{|c|c|c|c|c|c|c|c|c|}
\hline & \multicolumn{8}{|c|}{ Panel A: Mobiles for Payment of Bills (Mobile.Pay) } \\
\hline & \multicolumn{3}{|c|}{ Income Levels } & \multicolumn{5}{|c|}{ Regions } \\
\hline & LIC & LMIC & UMIC & $\mathrm{AP}$ & CEE & LA & MENA & SSA \\
\hline \multirow[t]{2}{*}{ Constant } & $35.314 * * *$ & $34.803 * *$ & 25.852 & 26.931 & 80.941 & -5.361 & na & $30.420 * * *$ \\
\hline & $(0.000)$ & $(0.017)$ & $(0.352)$ & $(0.159)$ & $(0.109)$ & $(0.774)$ & & $(0.000)$ \\
\hline \multirow[t]{2}{*}{ Mobile.Pay } & 1.604 & 5.688 & $18.549 * *$ & -8.245 & 1.374 & 43.778*** & & -6.240 \\
\hline & $(0.637)$ & $(0.262)$ & $(\mathbf{0 . 0 2 3})$ & $(0.291)$ & $(0.462)$ & $(0.002)$ & & $(0.233)$ \\
\hline \multirow[t]{2}{*}{ Mobile.Pay* HDI } & -2.692 & -7.863 & $-28.697 * *$ & 16.032 & -2.076 & $-57.509 * * *$ & & 12.550 \\
\hline & $(0.652)$ & $(0.245)$ & $(\mathbf{0 . 0 1 8})$ & $(0.212)$ & $(0.463)$ & $(\mathbf{0 . 0 0 2})$ & & $(0.227)$ \\
\hline \multirow[t]{2}{*}{ Educational Spending } & 14.488 & $30.809 * *$ & 31.096 & 16.766 & -48.097 & $56.829 * *$ & & 3.616 \\
\hline & $(0.254)$ & $(0.048)$ & $(0.352)$ & $(0.397)$ & $(0.297)$ & $(0.036)$ & & $(0.724)$ \\
\hline \multirow[t]{2}{*}{ Government Stability } & 0.014 & $-3.413 * * *$ & -0.250 & 0.147 & $-1.456 *$ & 0.356 & & 1.076 \\
\hline & $(0.978)$ & $(0.004)$ & $(0.176)$ & $(0.803)$ & $(0.072)$ & $(0.264)$ & & $(0.177)$ \\
\hline \multirow[t]{2}{*}{ Inflation } & 0.063 & $-0.920 * *$ & -0.161 & -0.904 & -0.146 & 0.075 & & 0.527 \\
\hline & $(0.908)$ & $(\mathbf{0 . 0 1 0})$ & $(0.489)$ & $(0.265)$ & $(0.775)$ & $(0.670)$ & & $(0.349)$ \\
\hline \multirow[t]{2}{*}{ Credit } & -0.118 & -0.035 & 0.068 & -0.0004 & -0.015 & 0.028 & & $0.100^{* *}$ \\
\hline & $(0.134)$ & $(0.425)$ & $(0.148)$ & $(0.993)$ & $(0.884)$ & $(0.551)$ & & $(\mathbf{0 . 0 1 9})$ \\
\hline \multirow[t]{2}{*}{ Foreign Direct Investment } & 0.347 & -0.357 & $-1.460 * *$ & -0.393 & 0.619 & -0.532 & & $0.570 *$ \\
\hline & $(0.595)$ & $(0.231)$ & $(\mathbf{0 . 0 3 1})$ & $(0.348)$ & $(0.187)$ & $(0.221)$ & & $(0.086)$ \\
\hline \multirow[t]{2}{*}{ Remittances } & -0.436 & 0.152 & -0.990 & 0.237 & -0.164 & 0.338 & & 0.020 \\
\hline & $(0.174)$ & $(0.547)$ & $(0.663)$ & $(0.578)$ & $(0.329)$ & $(0.181)$ & & $(0.965)$ \\
\hline $\mathrm{R}^{2}$ & 0.564 & 0.474 & 0.827 & 0.927 & 0.504 & 0.913 & & 0.619 \\
\hline Fisher & $11.01 * * *$ & $9.08^{* * * *}$ & $32.14 * * *$ & 4.70 & $5.86 * *$ & $19.28 * * *$ & & $11.28 * * *$ \\
\hline Observations & 23 & 27 & 17 & 11 & 15 & 13 & & 22 \\
\hline
\end{tabular}

Constant

Mobile.PS

Mobile.SR* HDI

Educational Spending

Government Stability

Inflation

Credit

Foreign Direct Investment

Remittances
Panel B: Mobiles for sending and receiving money (Mobile.SR)

\begin{tabular}{|c|c|c|c|c|c|c|c|}
\hline \multicolumn{3}{|c|}{ Income Levels } & \multicolumn{5}{|c|}{ Regions } \\
\hline LIC & LMIC & UMIC & $\mathrm{AP}$ & CEE & LA & MENA & SSA \\
\hline $38.100 * * *$ & $33.087 * *$ & 21.556 & 21.691 & $106.02 * *$ & -23.210 & & $29.806 * * *$ \\
\hline$(0.000)$ & $(0.024)$ & $(0.773)$ & $(0.305)$ & $(0.014)$ & $(0.213)$ & & $(0.000)$ \\
\hline-2.067 & 0.962 & $36.447 *$ & -21.371 & 31.426* & $22.437 * *$ & & -0.516 \\
\hline (0.309) & (0.194) & $(0.054)$ & $(0.162)$ & $(0.059)$ & $(0.041)$ & & $(0.291)$ \\
\hline 4.487 & -1.305 & $-54.756 *$ & 34.606 & $-42.67 *$ & $-30.876^{*}$ & & 0.962 \\
\hline$(0.274)$ & $(0.246)$ & $(\mathbf{0 . 0 5 8 )}$ & $(0.153)$ & $(0.058)$ & $(\mathbf{0 . 0 5 7})$ & & $(0.282)$ \\
\hline 10.216 & $33.217 * *$ & 35.075 & 14.331 & $-72.158 *$ & $74.182 * * *$ & & 10.550 \\
\hline$(0.374)$ & $(0.042)$ & $(0.590)$ & $(0.571)$ & $(0.056)$ & $(0.000)$ & & $(0.262)$ \\
\hline 0.372 & $-3.520 * * *$ & -0.832 & 0.487 & $-1.508 * *$ & -0.383 & & 0.446 \\
\hline$(0.376)$ & $(0.002)$ & $(0.336)$ & $(0.406)$ & $(0.049)$ & $(0.245)$ & & $(0.579)$ \\
\hline 0.091 & $-0.868 * *$ & -0.127 & -0.451 & -0.335 & 0.296 & & 0.359 \\
\hline$(0.843)$ & $(\mathbf{0 . 0 2})$ & $(0.788)$ & $(0.530)$ & $(0.389)$ & $(0.284)$ & & $(0.464)$ \\
\hline$-0.165 * *$ & -0.027 & 0.015 & 0.049 & -0.067 & 0.057 & & $0.117^{* *}$ \\
\hline$(\mathbf{0 . 0 3 0})$ & $(0.547)$ & $(0.725)$ & $(0.435)$ & $(0.422)$ & $(0.316)$ & & $(0.010)$ \\
\hline 0.404 & -0.465 & -0.694 & -0.334 & 0.746 & 0.332 & & 0.498 \\
\hline$(0.446)$ & $(0.142)$ & $(0.443)$ & $(0.405)$ & $(0.114)$ & $(0.524)$ & & $(0.125)$ \\
\hline$-0.444 * *$ & 0.153 & -1.586 & 0.296 & $-0.450 * *$ & $0.518^{*}$ & & -0.151 \\
\hline$(0.014)$ & $(0.554)$ & $(0.503)$ & $(0.559)$ & $(\mathbf{0 . 0 2 3})$ & $(0.073)$ & & (0.738) \\
\hline
\end{tabular}




\begin{tabular}{lllllll}
\hline $\mathrm{R}^{\mathbf{2}}$ & 0.626 & 0.470 & 0.819 & 0.871 & 0.587 & 0.913 \\
Fisher & $\mathbf{1 1 . 9 8} * * *$ & $\mathbf{3 . 9 6 * * *}$ & $\mathbf{1 3 . 3 1} * * *$ & $\mathbf{9 . 7 0 *}$ & $\mathbf{7 . 3 1} * *$ & $\mathbf{1 9 . 5 7 * * *}$ \\
Observations & 23 & 27 & 17 & 11 & 15 & 13 \\
\hline
\end{tabular}

***; **;: significance levels of 1\%, 5\% and 10\% respectively. LIC: Low Income Countries. LMIC: Lower Middle Income Countries. UMIC: Upper Middle Income Countries. AP: Asia and Pacific. CEE: Central and Eastern Europe. LA: Latin America. MENA: Middle East and North Africa. Mobile.Pay: Mobiles for the payment of bills. Mobile. SR: Mobiles for the Sending and Receiving in Money. HDI: Human Development Index. No regressions are performed for the MENA region because of issues with degrees of freedom.

Before we conclude, it is important to highlight some potential causal linkages. Mobile banking could interact with human development to reduce inequality and poverty for a multitude of reasons. The three main concepts of the human development index (health and long life, education and income) are articulated in the discourse because mobile banking services are closely related to the three components of human development.

First and foremost, a minimum amount of education is required to use mobile banking applications. It follows that previously unbanked segments of the population need some literacy in order to benefit from phone-related transfer and storage systems.

Second, mobile banking applications contribute to the income component of human development through cost-reduction mechanisms. Mobile banking services assists households in budget management, especially when they are faced with poverty-related shocks. This is essentially because mobile transfers enable timely responses to shocks and hence, a reduction in the potential cost of such shocks. Some of the cost mitigation channels include: saving of transportation cost and lower transaction cost. Apart from the saving of income, mobile banking services also enhance income generating activities. For instance, mobile banking services enable women to create new businesses and/or run existing ones more efficiently. This has poverty- and 'gender inequality'-mitigating externalities.

Third, health and long life can be positively influenced with mobile banking applications in the perspective that household security is likely to improve with the availability of a mobile phone associated with banking applications. For instance, a household's capacity to reduce the number of overnight days spent in the hospital can be enhanced with the fast dial of a mobile phone on the one hand and capability of the mobile phone on the other hand to comply with the financial obligations associated with the health issues. 


\section{Concluding implications, caveats and future research directions}

In developing countries, economic opportunities are being increasingly improved with the conversion of mobile phones into pocket banks to facilitate financial access to a substantial bulk of the population hitherto excluded from mainstream financial institutions (Demombynes \& Thegeya, 2012). Our results have shown that at certain thresholds of the human development index (HDI), financial access by means of mobile banking is positively related to inclusive development. Specifically, we have established the following: First, increased use of mobiles to pay bills is negatively correlated with: (i) poverty in lowermiddle-income countries (LMIC), upper-middle-income countries (UMIC) and Latin American countries (LA), respectively at HDI thresholds of $0.725,0.727$ and 0.778 and (ii) inequality in UMIC and LA with HDI thresholds of respectively 0.646 and 0.761 . Second, increased use of the mobile to send/receive money is negatively correlated with: (i) poverty in LMIC, UMIC and Central \& Eastern European countries (CEE) with corresponding HDI thresholds of $0.631,0.750$ and 0.750 and (ii) inequality in UMIC, CEE and LA at HDI thresholds of $0.665,0.736$ and 0.726 respectively.

The established negative relationship between mobile banking dynamics and negative signals of inclusive development (poverty and inequality) is in accordance with the literature on the appealing benefits of the mobile telephony in Section 2 (Ondiege, 2010; Al Surikhi, 2012; Ojo et al., 2012; Mishra and Bisht, 2013). Therefore, by employing macroeconomic mobile banking data from 93 developing nations to validate past studies that have been essentially based on microeconomic, country-specific and survey-based data, we have further confirmed the relevance of more comprehensive policy measures towards tackling apparent and challenging contemporary global issues of non-inclusive growth, inequality and poverty in developing countries. As a policy implication the inclusive externalities of mobile banking applications should be endowed with broader scope and not limited to country-specific contexts.

It is very surprising that the findings are not significant consistently for the SSA sample. We clarify this puzzling tendency with African-specific literature and stylized facts.

First, on stylized facts, according to Mosheni-Cheraghlou (2013), relative to other developing countries, the SSA sub-region enjoys high levels of mobile banking. Thus, we expected results of the SSA sample to be significant. The point is emphasized with the asymmetry between Russia and Somalia, whereas Russia occupies the $7^{\text {th }}$ position when it comes to mobile phone subscriptions in the world, it is also associated with countries in the 
bottom in terms of mobile banking applications, notably the use of mobile phones to pay bills and receive/send money. Conversely, a country like Somalia which occupies the $4^{\text {th }}$ lowest position in mobile phone penetration surprisingly ranks respectively $3^{\text {rd }}$ and $1^{\text {st }}$ in terms of using the mobile phone to pay bills and send/receive money. Mosheni-Cheraghlou partially elucidates this disparity by sustaining that regulation and technological availability are fundamental to mobile banking effectiveness. The position of Mosheni-Cheraghlou is consistent with the findings of Ojo et al. (2012) in Section 2 on policy requirements for the inclusive rewards of mobile phone/banking. Hence, in accordance with Ojo et al. the following policy measures are essential to boosting mobile banking benefits in SSA: "1) updating financial and telecommunication regulations to enable the provision of mobilebased services, e.g. mobile microfinance, to vulnerable groups, 2) mobilizing local communities in the production of local contents and 3) engaging non-governmental organizations in building the capacity of government agencies in mobile service delivery and in training vulnerable communities in the effective use of mobile technology to access information and services critical to their needs" (p. S30). It is also important to note that a high level of mobile money usage in some countries such as Somalia can also be traceable to the absence of other services/channels and lack of these services/channels does not automatically derive from human and/or economic development.

Second, in the relevant African-specific literature, results for SSA are not in conformity with Asongu (2015b) and Asongu \& Nwachukwu, (2016d). It is important to note that Asongu (2015b) has shown that mobile phones mitigate inequality in Africa, with this mitigating role higher when the mobile banking channel is involved (Asongu \& Nwachukwu, 2016d). Our findings may be inconsistent with the underlying studies for at least three reasons, notably, the corresponding literature: (i) samples all African countries; (ii) uses a 2003-2009 average mobile phone penetration growth rate and the year 2009 for other variables and (iii) employs macroeconomic financial/banking indicators as instruments for mobile phones in order to calibrate mobile banking.

Hence, in light of the above, the sheer availability of mobile phones and underlying banking applications do not represent ends for inclusive development. It is worthwhile for policy measures to be tailored towards channels that facilitate economic prosperity to trickle down to the poor, whether in relative (inequality mitigation) and/or absolute (poverty reduction) pro-poor terms. Therefore, our findings for the SSA region may not be surprising after all, given that the involved stylized facts show that it is the only region in the world 
where extreme poverty has been increasing since the 1990s, with 45 percent of countries in the region substantially off-track from attaining the MDGs extreme poverty target. Therefore, urgent policy action is needed given that the sub-region has been enjoying over two decades of growth resurgence (Fosu, 2014, p. 44) and the region is also currently hosting seven of the ten fastest growing economies (Asongu \& Rangan, 2016). As a policy implication, it is important to seriously consider the relevance of mobile banking in the post-2015 Sustainable Development Growth (SDGs) agenda.

Unfortunately, to the best of our knowledge, ongoing reports (e.g Vodafone SIM Project) have substantially built on the evidence that mobile banking does not feature prominently in ongoing discussions surrounding the SDGs agenda (Asongu \& De Moor, 2015). Perhaps a reason for this missing feature is the lack of substantial macroeconomic empirical evidence on the investigated relationship.

Given that the study is exploratory, the conclusion is informative and/or expositional about human development thresholds at which mobile banking is positively linked to inclusive development. Mobile phones are used interchangeably with mobile banking because of a minimalist approach adopted by the study. In essence, mobile banking variables that are used as independent variables of interest are complementary to the mobile phone. Hence, in the general discourse there is at least some assumption that the mobile phone is being used (or is potentially usable) for mobile banking services.

It is also interesting to note that the adoption of mobile devices in many places in the developing world is principally because of the absence of alternatives. Within this framework, the scope of mobile banking applications and corresponding risks associated with them are important in understanding their rate of adoption by financial institutions. For instance, smart mobile devices could offer a plethora of rewards, inter alia: fingerprint recognition and Global Positioning System (GPS) location information. Whereas these applications can help reduce the risk of fraud, malware is now common-place and can represent substantial risk for banking clients. Moreover, incorporating determinants (positive and negative) of 'mobile adoption' into the specification is difficult because the mobile phone is not used as the dependent variable but as an independent variable of interest.

It will be interesting for future research to focus on employing richer mobile banking data to investigate and establish causality in the underlying nexuses. Moreover, decomposing the HDI into its constituent elements to assess which components are most relevant in driving inclusiveness is also an interesting future line of inquiry. Future studies can also benefit from 
the new set of data provided by Findex in 2015 and more detailed information on the deployment of mobile money from the International Monetary Fund's Financial Access Database and the Committee on Payments and Market Infrastructure. 


\section{Appendices}

\section{Appendix 1: Definition of variables}

\begin{tabular}{|c|c|c|}
\hline Variable(s) & Definition(s) & Source(s) \\
\hline Poverty & $\begin{array}{l}\text { Poverty rate: Proportion (per cent) of the population living on one USD } \\
\text { a day }\end{array}$ & \multirow{2}{*}{$\begin{array}{l}\text { Mlachila et al. } \\
\qquad(2014)\end{array}$} \\
\hline Inequality & GINI index of Inequality & \\
\hline Mobiles for bills & Mobile phone used to pay bills (\% of Adults) & \multirow{2}{*}{$\begin{array}{l}\text { Mosheni- } \\
\text { Cheraghlou } \\
\text { (2013) }\end{array}$} \\
\hline $\begin{array}{l}\text { Mobiles to } \\
\text { receiving/sending }\end{array}$ & Mobile phone used to send/receive money (\% of Adults) & \\
\hline $\begin{array}{l}\text { Educational } \\
\text { Spending }\end{array}$ & $\begin{array}{l}\text { "Public resources allocated to education spending, as percent of GDP" } \\
\text { (p. 25) }\end{array}$ & $\begin{array}{l}\text { Mlachila et al. } \\
\qquad \text { (2014) }\end{array}$ \\
\hline $\begin{array}{l}\text { Government } \\
\text { Stability }\end{array}$ & $\begin{array}{l}\text { "Index ranging from } 0 \text { to } 12 \text { and measuring the ability of government } \\
\text { to stay in office and to carry out its declared program(s).The higher } \\
\text { the index, the more stable the government is" (p. 25). }\end{array}$ & $\begin{array}{l}\text { Mlachila et al. } \\
\text { (2014) }\end{array}$ \\
\hline Inflation & Inflation rate based on the Consumer Price Index (CPI) & $\begin{array}{l}\text { Mlachila et al. } \\
\qquad \text { (2014) }\end{array}$ \\
\hline $\begin{array}{l}\text { Credit to private } \\
\text { sector }\end{array}$ & $\begin{array}{l}\text { "Domestic credit to private sector, namely credit offered by the banks } \\
\text { to the private sector, as percent of GDP" (p. 25). }\end{array}$ & $\begin{array}{l}\text { Mlachila et al. } \\
\qquad \text { (2014) }\end{array}$ \\
\hline $\begin{array}{l}\text { Foreign Direct } \\
\text { Investment }\end{array}$ & "Net Inflows of Foreign Direct Investments, as percent of GDP" (p. 25) & $\begin{array}{l}\text { Mlachila et al. } \\
\text { (2014) }\end{array}$ \\
\hline Remittances & $\begin{array}{l}\text { "Workers' remittances and compensation of employees (Percent of } \\
\text { GDP), calculated as the sum of workers' remittances, compensation of } \\
\text { employees and migrants' transfers" (p. 25). }\end{array}$ & $\begin{array}{l}\text { Mlachila et al. } \\
\text { (2014) }\end{array}$ \\
\hline $\begin{array}{l}\text { Human } \\
\text { Development }\end{array}$ & $\begin{array}{l}\text { "Geometric mean of normalized indices measuring achievements in } \\
\text { three basic dimensions of human development: a long and healthy life, } \\
\text { access to knowledge and a decent standard of living" (p. 25) }\end{array}$ & $\begin{array}{l}\text { Mlachila et al. } \\
\text { (2014) }\end{array}$ \\
\hline
\end{tabular}

\begin{tabular}{lccccc} 
Appendix 2: Summary Statistics & \multicolumn{1}{c}{} \\
\hline & Mean & S. D & Minimum & Maximum & Obs \\
\cline { 2 - 6 } & 0.062 & 0.113 & 0.000 & 28.127 & 93 \\
Poverty rate & 41.844 & 8.339 & 28.127 & 65.27 & 78 \\
Inequality & 2.601 & 4.125 & 0.000 & 25.70 & 80 \\
Mobile for bills payment & 4.802 & 9.615 & 0.000 & 60.50 & 80 \\
Mobile for sending/receiving money & 0.701 & 0.211 & 0.202 & 1.000 & 93 \\
Educational spending & 0.734 & 0.189 & 0.284 & 0.995 & 93 \\
Health Spending & 2.626 & 2.242 & -0.379 & 11.278 & 93 \\
Government Stability & 7.909 & 4.106 & 2.202 & 21.669 & 90 \\
Inflation (log) & 39.730 & 34.036 & -14.660 & 169.251 & 90 \\
Domestic Credit (log) & 4.488 & 3.720 & 0.0007 & 20.869 & 92 \\
Foreign Direct Investment & 5.445 & 7.612 & 0.003 & 38.590 & 84 \\
Remittances & 0.580 & 0.152 & 0.280 & 0.809 & 93 \\
Human Development Index & & & & &
\end{tabular}

S.D: Standard Deviation. Obs: Observations. 


\begin{tabular}{|c|c|c|c|c|c|c|c|c|c|c|c|}
\hline \multicolumn{7}{|c|}{ Control variables } & \multicolumn{2}{|c|}{ Mobile banking } & \multicolumn{2}{|c|}{ Inclusive development } & \multirow[b]{3}{*}{ Educ } \\
\hline Educ & GovStab & Infl & Credit & FDI & Remit & HDI & MBills & MSR & Pov. & GINI & \\
\hline \multirow[t]{12}{*}{1.000} & 0.235 & 0.263 & 0.392 & 0.005 & 0.143 & 0.216 & 0.207 & -0.006 & -0.267 & 0.312 & \\
\hline & 1.000 & 0.277 & 0.324 & -0.125 & -0.063 & -0.098 & 0.080 & -0.182 & -0.171 & -0.188 & GovStab \\
\hline & & 1.000 & 0.199 & 0.171 & -0.059 & -0.138 & 0.300 & 0.130 & 0.129 & -0.019 & Infl \\
\hline & & & 1.000 & -0.202 & 0.530 & 0.387 & 0.082 & -0.183 & -0.367 & -0.185 & Credit \\
\hline & & & & 1.000 & -0.159 & 0.034 & -0.082 & 0.012 & 0.203 & 0.065 & FDI \\
\hline & & & & & 1.000 & -0.045 & -0.080 & -0.172 & -0.130 & 0.145 & Remit \\
\hline & & & & & & 1.000 & 0.088 & -0.136 & -0.638 & -0.024 & HDI \\
\hline & & & & & & & 1.000 & 0.865 & 0.142 & 0.039 & MBills \\
\hline & & & & & & & & 1.000 & 0.185 & 0.062 & MSR \\
\hline & & & & & & & & & 1.000 & 0.223 & Pov. \\
\hline & & & & & & & & & & 1.000 & GINI \\
\hline & & & & & & & & & & & QGI \\
\hline
\end{tabular}

Educ: Educational Spending. GovStab: Government Stability. Infl: Inflation. Credit: Domestic Credit. FDI: Foreign Direct Investment. Remit: Remittances. MBill: Mobile used for paying bills. MSR: Mobile used for sending/receiving Money. Pov: Poverty rate. GINI: inequality Index.

\section{References}

Ajzen, I., (1991). "The theory of planned behaviour". Organizational Behavior and Human Decision Processes, 50, pp. 179-211.

Ajzen, I., \& Fishbein, M. (1980). Understanding attitudes and predicting social behavior. Englewood Cliffs, NJ: Prentice-Hall.

Aker, J. C., \& Fafchamps, M., (2010). "How Does Mobile Phone Coverage Affect Farm-Gate Prices? Evidence from West Africa", Department of Economics and the Fletcher School, Tufts University.

Akturan, U., \& Tezcan, N., (2012). "Mobile banking adoption of the youth market: Perceptions and intentions", Marketing Intelligence \& Planning, 30, (4), pp. 444-459.

Al Surikhi, H. F., (2012). "Knowledge and Financial Management in Households: An Examination of Married Women's Perspectives in Chadbourn, North Carolina", Capstone Collection, Paper No. 2489.

Alsheikh, L., \& Bojei, J., (2014). "Determinants Affecting Customer's Intention to Adopt Mobile Banking in Saudi Arabia", International Arab Journal of e-Technology, 3(4), pp. 210219.

Anand, R., Mishra, S., \& Peiris, S. J., (2013). "Inclusive Growth: Measurement and Determinants", IMF Working Paper No. 13/135, Washington.

Anand, R., Mishra, S., \& Spatafora, N., (2012), "Structural Transformation and the Sophistication of Production," IMF Working Paper No. 12/59, Washington.

Andrés, A. R. (2006). "Software piracy and income inequality". Applied Economic Letters, 13 (2), pp. 101-105. 
Anyanwu, J. C., (2014a). "Determining the correlates of poverty for inclusive growth in Africa", European Economics Letters, 3(1), pp. 12-17.

Anyanwu, J. C., (2014b). "Marital Status, Household Size and Poverty in Nigeria: Evidence from the 2009/2010 Survey Data", African Development Review, 26(1), pp. 118-137.

Anyanwu, J. C., (2013a). "The correlates of poverty in Nigeria and policy implications", African Journal of Economic and Sustainable Development, 2(1), pp. 23-52.

Anyanwu, J. C., (2013b). "Gender Equality in Employment in Africa: Empirical Analysis and Policy Implications”, African Development Review, 25(4), pp. 400-420.

Asongu, S. A., (2013a). "How has mobile phone penetration stimulated financial development in Africa", Journal of African Business, 14(1), pp. 7-18.

Asongu, S. A., (2013b). "Investment and Inequality in Africa: Which Financial Channels Are Good for the Poor", African Finance Journal, 15(2), pp. 43-65.

Asongu, S. A., (2015a). "Conditional Determinants of Mobile Phones Penetration and Mobile Banking in Sub-Saharan Africa", Journal of the Knowledge Economy,

DOI: 10.1007\%2Fs13132-015-0322-z.

Asongu, S. A., (2015b). "The impact of mobile phone penetration on African inequality", International Journal of Social Economics, 42(8), pp. 706-716.

Asongu, S. A., (2016). "Reinventing foreign aid for inclusive and sustainable development: Kuznets, Piketty and the Great Policy Reversal", Journal of Economic Surveys, 30(4), pp. 736-755.

Asongu, S. A., \& Nwachukwu, J. C. (2016a). "Welfare Spending and Quality of Growth in Developing Countries: A Note on Evidence from Hopefuls, Contenders and Best Performers", The Social Science Journal, 53(4), pp. 495-500.

Asongu, S. A., \& Nwachukwu, J. C., (2016b). "Mobile phones in the diffusion of knowledge and persistence in inclusive human development in Sub-Saharan Africa", Information Development, DOI: 10.1177/0266666916655189.

Asongu, S. A., \& Nwachukwu, J. C., (2016c). "The role of governance in mobile phones for inclusive human development in Sub-Saharan Africa", Technovation, 55-56(SeptemberOctober), pp. 1-13.

Asongu, S. A., \& Nwachukwu, J. C., (2016d). "Mobile Phone Penetration, Mobile Banking and Inclusive Development in Africa”, African Finance Journal, 18(1), pp. 34-52.

Asongu, S. A, \& De Moor, L., (2015). "Recent advances in finance for inclusive development", African Governance and Development Institute Working Paper No. 15/005, Yaoundé. 
Asongu, S. A., \& Kodila-Tedika, O., (2015). “Is Poverty in the African DNA (Gene)?”, African Governance and Development Institute Working Paper No. 15/011, Yaoundé.

Asongu, S. A., \& Rangan, G., (2016). "Trust and Quality of Growth: A Note", Economics Bulletin, 36(3), pp. 1854-1867.

Aricat, R. G., (2015). "Is (the study of) mobile phones old wine in a new bottle? A polemic on communication-based acculturation research", Information Technology \& People, 28(4), pp.806-824.

Bagozzi, R., (1982). "A field investigation of causal relations among cognitions, affect, intentions, and behaviour", Journal of Marketing Research, 19 (4), pp. 562-584.

Baliamoune-Lutz, M., \& McGillivray, M., (2009). "Does Gender Inequality Reduce Growth in Sub-Saharan Africa and Arab Countries?", African Development Review, 21(2), pp. 224242.

Baliamoune-Lutz, M., (2007). “Globalisation and Gender Inequality: Is Africa Different?”, Journal of African Economies, 16(2), pp. 301-348.

Barro, R., \& Lee, J., (2010), “A New Data Set of Educational Attainment in the World, 19502010”, NBER Working Paper No. 15902 (Cambridge, Massachusetts: National Bureau of Economic Research).

Bauer, S., De Niet, J., Timman, R., \& Kordy, H., (2010). "Enhancement of care through selfmonitoring and tailored feedback via text messaging and their use in the treatment of childhood overweight", Patient Education and Counseling, 79 (2010), pp. 315-319.

Brambor, T., Clark, W. M., \& Golder, M., (2006), “Understanding Interaction Models: Improving Empirical Analyses", Political Analysis, 14 (1), pp. 63-82.

Calderon C., \& Servén, L., (2004), "The Effects of Infrastructure Development on Growth and Income Distribution," World Bank Policy Research Working Paper No. 3400, Washington.

Caulderwood, K., (2015). "Mobile Banking Market In Sub-Saharan Africa Could Be Worth \$1.3B In Four Years", International Business Times, http://www.ibtimes.com/mobile-banking-market-sub-saharan-africa-could-be-worth-13bfour-years-1788648 (Accessed: 24/03/2015).

Chan, A., \& Jia, T., (2011). "The Role of Mobile Banking in Facilitating Rural Finance: Reducing Inequality in Financial Services between Urban and Rural Areas", Accenture Banking Services, http://www.accenture.com/SiteCollectionDocuments/PDF/PoV-MobileBanking-051611-EN.pdf (Accessed: 17/03/2015).

Cudjoe, A. G., Anim, P. A., \& Nyanyofio, J., (2015). "Determinants of Mobile Banking Adoption in the Ghanaian Banking Industry: A Case of Access Bank Ghana Limited", Journal of Computer and Communications, 3, pp. 1-19. 
Da Costa, T. M. Salomão, P. L., Martha, A. S., Pisa, I. T., \& Sigulem, D., (2010). "The impact of short message service text messages sent as appointment reminders to patients' cell phones at outpatient clinics in São Paulo, Brazil", International Journal of Medical Informatics, 79 (2010), pp. 65-70.

Daud, M., Kassim, N., Said, W., \& Noor, M., (2011). "Determining Critical Success Factors of Mobile Banking Adoption in Malaysia", Australian Journal of Basic and Applied Sciences, 5(9), pp. 252-265.

Demombynes, G., \& Thegeya, A., (2012, March). "Kenya's Mobile Revolution and the Promise of Mobile Savings", World Bank Policy Research Working Paper, No. 5988.

Dollar, D., Kleineberg, T., \& Kraay, A., (2013), “Growth is Still Good for the Poor," World Bank Policy Research Working Paper No. 6568 (Washington: World Bank).

Dollar, D., Kleineberg, T., \& Kraay, A., (2002),, "Growth is Good for the Poor," Journal of Economic Growth, Vol. 7, No. 3, pp. 195-225.

Dollar, D., \& Kraay, A., (2003), "Institutions, Trade, and Growth," Journal of Monetary Economics, 50, (1), pp. 133-162.

E-agriculture (2012). "Using ICT to enable Agricultural Innovation Systems for Smallholders", e-source book, ICT In Agriculture, Connecting Small Holders to Knowledge, Networks and Institutions, (Forum 4, September 2012). http://www.fao.org/docrep/018/ar130e/ar130e.pdf (Accessed: 18/03/2015).

Elu J., \& Loubert, L., (2013). "Earnings Inequality and the Intersectionality of Gender and Ethnicity In SubSaharan Africa: The Case of Tanzanian Manufacturing", American Economic Review, Papers and Proceedings 04/2013, 103(103), pp. 289-292.

Fishbein, M., \& Ajzen, I. (1975). Belief, attitude, intention, and behavior: An introduction to theory and research. Reading, MA: Addison-Wesley.

Fosu, A. K., (2015). "Growth, Inequality and Poverty in Sub-Saharan Africa: Recent Progress in a Global Context", Oxford Development Studies, 43(1), pp. 44-59.

Gripenberg, P., (2011). "Computer self-efficacy in the information society: Design of learning strategies, mechanisms and skill areas", Information Technology \& People, 24(3), pp.303 331.

Gu, J-C., Lee, S-C., \& Suh, Y-H., (2009). "Determinants of behavioral intention to mobile banking”, Expert Systems with Applications, 36(9), pp. 11605-11616.

Hoffman, J. A., Cunningham, J. R., Suleh, A. J., Sundsmo, A., Dekker, D., Vago, F., \& Munly, K., (2010). "Mobile Direct Observation Treatment for Tuberculosis Patients A Technical Feasibility Pilot Using Mobile Phones in Nairobi, Kenya", American Journal of Preventive Medicine, 39(1), pp. 78-80. 
Hossain, M. A., \& Quaddus, M., (2011). "The adoption and continued usage intention of RFID: an integrated framework", Information Technology \& People, 24(3), pp.236-256.

Ianchovichina, E., \& Gable, S. L., (2012), "What is Inclusive Growth?” in Commodity Prices and Inclusive Growth in Low-Income Countries, ed. by Rabah Arezki, Catherine Pattillo, Marc Quintyn, and Min Zhu, International Monetary Fund.

IMF (2007), "Globalization and Inequality," World Economic Outlook, Chapter 4, October, Washington DC.

Johri, A., \& Nair, S., (2011). "The role of design values in information system development for human benefit", Information Technology \& People, 24(3), pp.281-302.

Jonathan, D., \& Camilo, T. (2008). Mobile banking and economic development: Linking adoption, impact and use. Asian Journal of Communication, 18(4), 318-322.

Kautz, K., (2011). "Investigating the design process: participatory design in agile software development", Information Technology \& People, 24(3), pp.217-235.

Kazi, A. K., \& Mannan, M. A., (2013). "Factors affecting adoption of mobile banking in Pakistan: Empirical Evidence", Bukhari Institute of Technology, Karachi, Pakistan https://ideas.repec.org/a/rbs/ijbrss/v2y2013i3p54-61.html (Accessed: 26/03/2015).

Kelsey D \& le Roux, S., (2016), "Dragon Slaying with Ambiguity: Theory and Experiments", Journal of Public Economic Theory. doi: 10.1111/jpet.12185.

Kirui, O. K., Okello, J. J., Nyikal, R. A., \& Njiraini, G. W., (2013). "Impact of Mobile PhoneBased Money Transfer Services in Agriculture: Evidence from Kenya", Quaterly Journal of International Agriculture, 52(2), pp. 141-162.

Kliner, M., Knight, A., Mamvura, C., Wright, J., \& Walley, J., (2013). "Using no-cost mobile phone reminders to improve attendance for HIV test results: a pilot study in rural Swaziland", Infectious Diseases of poverty, 2(12), pp. 1-7.

Kodila-Tedika, O., \& Asongu, S. A., (2015). "The effect of intelligence on financial development: a cross-country comparison”, Intelligence, 51(July-August), pp. 1-9.

Kreps, D., \& Kimppa, K., (2015). "Theorising Web 3.0: ICTs in a changing society", Information Technology \& People, 28(4), pp.726 - 741.

Lahtiranta, J., Koskinen, J. S. S., Knaapi-Junnila, S., \& Nurminen, M., (2015). "Sensemaking in the personal health space", Information Technology \& People, 28(4), pp.790-805.

Le Roux, S., \& Kelsey, D., (2016). "Dragon Slaying with Ambiguity: Theory and Experiments", Sara le Roux, Department of Economics, Oxford Brookes University.

Lennerfors, T. T., Fors, P., \& van Rooijen, J., (2015). "ICT and environmental sustainability in a changing society: The view of ecological World Systems Theory", Information Technology \& People, 28 (4), pp.758-774. 
Levine, R., (2005). "Finance and Growth: Theory and Evidence," Philippe Aghion \& Steven Durlauf (eds.), Handbook of Economic Growth, Edition 1, Volume 1, chapter 12, pp. 865-934.

Martinez, M., \& Mlachila, M., (2013), "The Quality of the Recent High-Growth Episode in Sub-Saharan Africa," IMF Working Paper 13/53 (Washington: International Monetary Fund).

Maurer, B. (2008, May). Retail electronic payments systems for value transfers in the developing world. Department of Anthropology, University of California.

Medhi, I., Ratan, A., \& Toyama, K., (2009). "Mobile-Banking Adoption and Usage by Low-Literate, Low-Income Users in the Developing World", Internationalization, Design and Global Development, Lecture Notes in Computer Science, Volume 5623, 2009, pp 485494.

Mishra, V., \& Bisht, S. S., (2013). "Mobile banking in a developing economy: A customercentric model for policy formulation”, Telecommunications Policy, 37, pp. 503-514.

Mishra, S., Gable, S. L., \& Anand, R., (2011), "Service Export Sophsitication and Economic Growth," World Bank Policy Working Paper No. 5606, Washington.

Mlachila, M., Tapsoba, R., \& Tapsoba, S. J. A., (2014). “A Quality of Growth Index for Developing Countries: A Proposal”, IMF Working Paper No. 14/172, Washington.

Mosheni-Cheraghlou, A., (2013). "Mobile Banking: Who is in the Driver's Seat?", Working for a World Free of Poverty, The World Bank,

http://blogs.worldbank.org/allaboutfinance/mobile-banking-who-driver-s-seat (Accessed: 19/03/2015).

Mpogole, H., Usanga, H., \& Tedre, M., (2008). "Mobile phones and poverty alleviation: a survey study in rural Tanzania", Proceedings of M4D 2008, Karlstad University, Sweden, pp. $62-72$.

Muto, M., \& Yamano, T., (2009). "The Impact of Mobile Phone Coverage Expansion on Market Participation: Panel Data Evidence from Uganda", World Development, 37(12), pp. 1887-1896.

Ojo, A., Janowski, T., \& Awotwi, J., (2012). "Enabling development through governance and mobile technology”, Government Information Quarterly, 30 (2013), pp. S32-S45.

Ola-David, O., \& Oyelaran-Oyeyinka, O., (2014). "Smart Economics: Inclusive Growth, Poverty Alleviation and Decent Employment in Nigeria", SSRN Working Paper http://papers.ssrn.com/sol3/papers.cfm?abstract_id=2505264 (Accessed: 30/12/2014).

Ondiege, P., (2013). "Fostering financial inclusion with mobile banking", African Development Bank.

http://www.proparco.fr/webdav/site/proparco/shared/PORTAILS/Secteur_prive_developpeme nt/PDF/SPD16/SPD16_Peter_Ondiege_UK.pdf (Accessed: 03/02/2015). 
Ondiege, P., (2010). "Mobile Banking in Africa: Taking the Bank to the People", Africa Economic Brief, 1(8), pp. 1-16.

Patrignani, N, \& Whitehouse, D., (2015). "Slow tech: bridging computer ethics and business ethics”, Information Technology \& People, 28(4), pp.775-789.

Penard, T., Poussing, N., Yebe, G. Z., \& Ella, P. N., (2012). "Comparing the Determinants of Internet and Cell Phone Use in Africa: Evidence from Gabon ", Communications \& Strategies, 86, pp. 65-83.

Perez, F., Gonzalez, C. J., \& Aaronson, X., (2011). "Village banking development model: FINCA Costa Rica", Journal of Business Research, 64 (2011), pp. 316-324.

Qiang, C. Z., Kuek, S. C., Dymond, A., \& Esselaar, S., (2011). "Mobile Applications for Agricultural and Rural Development", ICT Sector Unit, World Bank http://siteresources.worldbank.org/INFORMATIONANDCOMMUNICATIONANDTECHN OLOGIES/Resources/MobileApplications_for_ARD.pdf (Accessed: 17/03/2015).

Ravallion, M., \& Chen, S., (2003), "Measuring Pro-Poor Growth," Economics Letters, 78, pp. 93-99.

Seneviratne, D., \& Sun, Y., (2013), "Infrastructure and Income Distribution in ASEAN-5: What are the Links?" IMF Working Paper No. 13/41, Washington.

Singh, A. B., (2012). "Mobile banking based money order for India Post: Feasible model and assessing demand potential", Procedia - Social and Behavioral Sciences, 37, pp. 466-481.

Tatnall , A., (2015). "Computer education and societal change: History of early courses in computing in universities and schools in Victoria", Information Technology \& People, 28(4), pp. $742-757$.

Venable, J. R., Pries-Heje, J., Bunker, D., Russo, N. L., (2011). "Design and diffusion of systems for human benefit: Toward more humanistic realisation of information systems in society”, Information Technology \& People, 24(3), pp.208-216.

Warren, M., (2007). "The digital vicious cycle: links between social disadvantage and digital exclusion in rural areas". Telecommunications Policy, 31(6-7), pp. 374-388.

Watts, S., \& Wyner, G., (2011). "Designing and theorizing the adoption of mobile technology-mediated ethical consumption tools", Information Technology \& People, 24(3), pp. 257-280.

West, D. M., (2013). "Improving Health Care through Mobile Medical Devices and Sensors", Centre for Technology and Innovation at Brookings, http://www.brookings.edu/ /media/research/files/papers/2013/10/22\%20mobile\%20medical \%20devices\%20west/west_mobile\%20medical\%20devices_v06 (Accessed: 19/03/2015).

World Bank (2015). “World Development Indicators', World Bank Publications http://www.gopa.de/fr/news/world-bank-release-world-development-indicators-2015 (Accessed: 25/04/2015). 
Yousafzai, S. Y., Foxall, G. R., \& Pallister, J. G., (2010). "Explaining Internet Banking Behavior: Theory of Reasoned Action, Theory of Planned Behavior, or Technology Acceptance Model?", Journal of Applied Social Psychology, 2010, 40(5), pp. 1172-1202.

Yousafzai, S., Foxall, G. R., \& Pallister, J. (2007a). “Technology acceptance: A meta-analysis of the TAM. Part 1". Journal of Modelling in Management, 2(3), pp. 251-280.

Yousafzai, S., Foxall, G. R., \& Pallister, J. (2007b). Technology acceptance: A meta-analysis of the TAM. Part 2. Journal of Modelling in Management, 2(3), pp. 281-304. 